Research Article

\title{
To Determine Awareness Knowledge and Acceptability of Family Planning Methods in Postpartum Women in Tertiary Care Centre
}

\author{
Dr. Priyanka Singh ${ }^{1}$, Dr. Girdhar Gopal Nagar ${ }^{2 *}$, Dr. Khushboo Meena ${ }^{3}$ \\ 1. Assistant professor department of obstetrics and gynecology at Govt. Medical college Kota, 28/304 Amar house Gumanpura, Kota, \\ 324007, India. \\ 2. Senior resident in department of gynecology and obstetrics at Govt. Medical Kota, V/P Kishanganj Baran, 325216 (Raj.), India. \\ 3. Assistant professor department of obstetrics and gynecology at Govt. Medical college Kota, KR-75 Civil lines, Nayapura, Kota 324001, \\ India.
}

*Corresponding author's E-mail: ggopalnagar@gmail.com

Received: 18-05-2021; Revised: 22-07-2021; Accepted: 30-07-2021; Published on: 15-08-2021.

\section{ABSTRACT}

Contraceptives unlock one of the most dormant, but potentially powerful assets in the development of women as the decision-maker. When women have the power to make choices about their families, they tend to decide precisely what demographers, economists and development experts recommend. They invest in the long-term human capital of their families.... Melinda Gates. India is the second most populous country in the world. There has been an increase in contraceptive prevalence and a reduction in total fertility rate since the launch of National Family Welfare Program in 1951. For better results, contraceptive use should start right from the postpartum period. Keeping it in mind, the study was conducted to determine the knowledge, attitude and practice of contraception among the postpartum women. It was prospective and observational study in the department of obstetrics and gynecology of Government medical college and hospital, Kota between 1 July 2020 to 31 December 2020. Study was conducted on 4480 postpartum women who delivered in this institution and came for follow-up. Women were interrogated and counselled regarding various methods of contraception using a preformed questionnaire. Their knowledge and attitude about contraception were assessed. Only $60.04 \%$ women were aware about various methods of contraception. This awareness increased with increasing education, parity and better socioeconomic class. Awareness was maximum for Sterilization $(90 \%)$ followed by barrier method $(80 \%)$ and intrauterine contraceptive device (76\%). Health care system $(43.86 \%)$ and media communication $(34.57 \%)$ was most common source of awareness. After counselling $81.02 \%$ women had accepted contraceptive method. The main reason for non acceptance of contraception was desire of more children. Contraceptive services can be strengthened by incorporating with antenatal services and providing post-partum contraceptive counseling.

Keywords: Knowledge, Awareness, Contraception, Postpartum women , Counseling, Acceptance.

QUICK RESPONSE CODE $\rightarrow$

DOI:

10.47583/ijpsrr.2021.v69i02.026

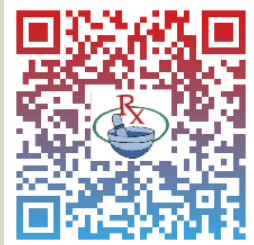

DOI link: http://dx.doi.org/10.47583/ijpsrr.2021.v69i02.026

\section{INTRODUCTION}

ndia is the second most populous country in the world after China ${ }^{2}$. The causes of increase population are poor family planning practices, reduced mortality rates and availability of good medical services.

The recently released survey data from National Family Health Survey - NFHS 5 (2019-20) for 17 states and five union territories (UTs) offers a silver lining. Still there are areas of concern that need attention. For instance, a disproportionate burden for use of modern methods of contraception continues to fall on Indian women. Of all modern methods, female sterilization is the most used method (75.3 per cent) followed by Condoms (11.7 per cent) and Pills (8.6 per cent).So even as we celebrate
India's progress towards achieving population stabilization, we must continue to plug implementation gaps in the country's family planning program. India must remain focused on delivering high quality family planning services to those who need it, adolescent, reproductive age group population and postpartum women. This would include expanding the basket of contraceptive choices, especially Long Acting Reversible Contraceptives (LARC), which are critical in view of our large population of adolescent $s$ and youth. The present study was carried out with the aim to study contraception awareness of post natal women. The postpartum period plays a very important role in initiating contraception. Women attend the health care system for delivery and are highly motivated at this period to avoid another pregnancy ${ }^{3}$. The most important population having unmet need for contraception is the postpartum women within one year of childbirth ${ }^{4}$.

\section{MATERIALS AND METHODS}

A total of 5598 postpartum women were enrolled out of which 1118 were lost to follow up so only 4480 women were finally enrolled. A prospective observational type study was conducted on 4480 post-partum women who 
delivered between 1 July 2020 to 31 December 2020 in the department of obstetrics and gynecology Govt. Medical College Kota. Both vaginal and cesarean delivered women who came for follow-up and were within 42 days of their postpartum period were included. The study was conducted using a preformed questionnaire with an attempt to understand the knowledge, awareness and attitude towards contraception after obtaining their informed consent. Women where the pregnancy outcome was still births or neonatal death, women with postpartum complications, women who have refused for follow up were excluded. They were counselled about various contraception methods available and allowed to choose a method of their choice. The list of questionnaire included demographic data like age, religion, residential area, education and occupation of both the partners, parity etc., data on awareness about the various methods of contraception, their source of information. All women, both participants as well as non-participants offered health education, regarding contraceptive methods and referral services. Post counselling which method of contraception preferred was studied to know the most common method of contraception chosen.

\section{RESULTS}

Table 1: Distribution according to Socio-demographic profile of participants:

Total no.

\begin{tabular}{|c|c|c|c|c|}
\hline \multirow[t]{6}{*}{1.} & \multirow[t]{6}{*}{ Age in years } & $18-20$ & 350 & 7.81 \\
\hline & & $21-25$ & 1960 & 43.75 \\
\hline & & $26-30$ & 800 & 17.35 \\
\hline & & $30-35$ & 1235 & 27.56 \\
\hline & & $>35$ & 135 & 3.01 \\
\hline & & & 4480 & \\
\hline \multirow[t]{3}{*}{2.} & \multirow[t]{3}{*}{ Residence } & Rural & 3120 & 69.64 \\
\hline & & Urban & 1360 & 30.36 \\
\hline & & & 4480 & \\
\hline \multirow[t]{3}{*}{3.} & \multirow[t]{3}{*}{ Parity } & P1 & 2060 & 46 \\
\hline & & Multiparous & 2420 & 54 \\
\hline & & & 4480 & \\
\hline \multirow[t]{6}{*}{4.} & \multirow{6}{*}{$\begin{array}{l}\text { Socioeconomic } \\
\text { classes }\end{array}$} & Upper & 170 & 3.82 \\
\hline & & Upper middle & 575 & 12.92 \\
\hline & & Lower middle & 840 & 18.75 \\
\hline & & Upper lower & 1230 & 27.45 \\
\hline & & Lower & 1665 & 37.16 \\
\hline & & & 4480 & \\
\hline \multirow[t]{4}{*}{5.} & \multirow[t]{4}{*}{ Religion } & Hindus & 3140 & 70.10 \\
\hline & & Muslims & 1250 & 27.90 \\
\hline & & Others & 90 & 2.00 \\
\hline & & & 4480 & \\
\hline \multirow[t]{4}{*}{6.} & \multirow[t]{4}{*}{ Education } & Uneducated & 850 & 18.97 \\
\hline & & Up to 8 class & 1810 & 40.40 \\
\hline & & $10^{\text {th }}$ pass & 1230 & 27.45 \\
\hline & & $12^{\text {th }}$ pass & 410 & 9.15 \\
\hline
\end{tabular}

\begin{tabular}{|c|c|c|c|c|}
\hline & & $\begin{array}{l}\text { Graduates } \\
\text { and } \\
\text { Postgraduates }\end{array}$ & 180 & 4.01 \\
\hline & & & 4480 & \\
\hline \multirow[t]{3}{*}{7.} & \multirow[t]{3}{*}{ Occupation } & Housewife & 3760 & 83.93 \\
\hline & & Working & 720 & 16.07 \\
\hline & & & 4480 & \\
\hline
\end{tabular}

Table 1 depicts the distribution of women according to Socio-demographic profile. It revealed that maximum (61.10\%) belonged to the age group 21-30yrs and least belonged to age > 35 years. $69.64 \%$ of women were residing in rural areas and $54 \%$ were multifarious.

$37.16 \%$ women were of lower class and $27.45 \%$ were of upper lower class based on modified Kuppuswamy scale. Most of the women (71.10\%) were Hindu. Majority $81.03 \%$ were literate, out of which $40.40 \%$ were educated up to $8^{\text {th }}$ class and $27.45 \%$ upto $10^{\text {th }}$ class. Majority $83.93 \%$ were house wives. Only $16.07 \%$ were employed.

Table 2: Association of sociodemographic factors with awareness level:

\begin{tabular}{|c|c|c|c|c|c|}
\hline \multirow[b]{2}{*}{1.} & \multirow[b]{2}{*}{ Age in years } & \multicolumn{2}{|c|}{ Aware (\%) } & \multicolumn{2}{|c|}{ Unaware } \\
\hline & & $18-20$ & 110 & 31.42 & 240 \\
\hline & & $21-25$ & 870 & 44.38 & 1090 \\
\hline & & $26-30$ & 600 & 75.00 & 200 \\
\hline & & $30-35$ & 990 & 80.16 & 245 \\
\hline & & $>35$ & 120 & 88.89 & 15 \\
\hline & & & 2690 & & \\
\hline \multirow[t]{3}{*}{2.} & \multirow[t]{3}{*}{ Residence } & Rural & 1750 & 56.08 & 1370 \\
\hline & & Urban & 940 & 69.11 & 420 \\
\hline & & & 2690 & & \\
\hline \multirow[t]{3}{*}{3.} & \multirow[t]{3}{*}{ Parity } & P1 & 1190 & 57.76 & 870 \\
\hline & & Multiparty & 1500 & 61.98 & 920 \\
\hline & & & 2690 & & \\
\hline \multirow[t]{6}{*}{4.} & \multirow{6}{*}{$\begin{array}{l}\text { Socioeconomic } \\
\text { classes }\end{array}$} & Upper & 160 & 94.11 & 10 \\
\hline & & Upper middle & 440 & 76.52 & 135 \\
\hline & & Lower middle & 600 & 71.42 & 240 \\
\hline & & Upper lower & 830 & 67.47 & 400 \\
\hline & & Lower & 660 & 39.63 & 1005 \\
\hline & & & 2690 & & \\
\hline \multirow[t]{4}{*}{5.} & \multirow[t]{4}{*}{ Religion } & Hindus & 1920 & 61.14 & 1220 \\
\hline & & Muslims & 700 & 56.00 & 550 \\
\hline & & Others & 70 & 77.78 & 20 \\
\hline & & & 2690 & & \\
\hline \multirow[t]{6}{*}{6.} & \multirow[t]{6}{*}{ Education } & Uneducated & 275 & 32.35 & 575 \\
\hline & & Up to 8 class & 979 & 54.08 & 831 \\
\hline & & $10^{\text {th }}$ pass & 910 & 73.98 & 320 \\
\hline & & $12^{\text {th }}$ pass & 360 & 87.80 & 50 \\
\hline & & $\begin{array}{l}\text { Graduates and } \\
\text { Postgraduates }\end{array}$ & 166 & 92.22 & 14 \\
\hline & & & 2690 & & \\
\hline \multirow[t]{3}{*}{7.} & \multirow[t]{3}{*}{ Occupation } & Housewife & 2100 & 55.85 & 1660 \\
\hline & & Working & 590 & 81.94 & 130 \\
\hline & & & 2690 & & \\
\hline
\end{tabular}


Table 2 shows that only $60.04 \%$ (2690) of women were aware about various methods of contraception. Awareness about contraceptive methods was more in women of > 35 years of age $(88.89 \%)$, urban women (69.11\%), multiparous (61.98\%), belonging to upper socioeconomic status, Hindu women (61.14\%) and women educated Upto high school (73.98\%).

Table 3: Source of knowledge in aware:

\begin{tabular}{|l|c|c|}
\hline Source & No. & $\%$ \\
\hline Health care system & 1180 & 43.86 \\
\hline Media communication & 930 & 34.57 \\
\hline Family members & 580 & 21.56 \\
\hline Total & 2690 & \\
\hline
\end{tabular}

Table 3 shows Most common source of knowledge in aware women was health care system $(43.86 \%)$ and least common was through family members (21.56\%).

Table 4: Known method among aware:

\begin{tabular}{|l|l|c|c|}
\hline Method & Type of method & No. & \% \\
\hline Single method & Barrier method & 2152 & 80.0 \\
\hline & OCP (POP) & 1560 & 58.0 \\
\hline & IUCD & 2044 & 76.0 \\
\hline & DMPA & 1292 & 48.0 \\
\hline & Lactational & 215 & 8.0 \\
\hline $\begin{array}{l}\text { amenorrhoea } \\
\text { Sterilization }\end{array}$ & 2421 & 90.0 \\
\hline $\begin{array}{l}\text { More than one } \\
\text { method }\end{array}$ & & 1450 & 53.90 \\
\hline
\end{tabular}

Table 4: Among aware women most common known method of contraception was Female sterilization (90.0\%) followed by barrier method (80.0\%) and IUCD (76.0\%). $53.90 \%$ of women were aware for more than one method.

Table 5: Willingness to use Contraception after postcounseling:

\begin{tabular}{|l|c|c|}
\hline Willingness & No. & $\%$ \\
\hline Yes & 3630 & 81.02 \\
\hline No & 850 & 18.98 \\
\hline Total & 4480 & \\
\hline
\end{tabular}

Table no. 5 showing $81.02 \%$ women showed Willingness to use Contraception after counselling.

Table 6: Reason for non - acceptance:

\begin{tabular}{|l|c|c|}
\hline Reason & No. & $\%$ \\
\hline Non specific & 129 & 15.17 \\
\hline Afraid of side effect & 51 & 6.0 \\
\hline Opposition of family/Husband & 110 & 12.94 \\
\hline Lack of knowledge/Access & 144 & 16.94 \\
\hline Wants more children & 416 & 48.94 \\
\hline Total & 850 & \\
\hline
\end{tabular}

Table 6 shows Desire of more children was most common reason (48.94\%) for non-acceptance of contraception.

Table 7: Distribution of preferred contraception in postcounseling willing user:

\begin{tabular}{|l|c|c|}
\hline Method & No. & \% \\
\hline Barrier & 1343 & 36.99 \\
\hline OCP (POP) & 580 & 15.98 \\
\hline IUCD & 1037 & 28.56 \\
\hline DMPA & 92 & 2.53 \\
\hline Female sterilization & 558 & 15.37 \\
\hline & 3630 & \\
\hline
\end{tabular}

Table 7 shows Post counselling and after giving cafeteria approach, $81.02 \%$ women were willing to use contraception. Choice preference was barrier method in $36.99 \%$, IUCD in $28.56 \%$, Depo-Provera in $2.53 \%$, progesterone pills in $15.98 \%$ and female sterilization in $15.37 \%$.

\section{DISCUSSION}

This was a prospective and observational study aimed to find out acceptance and awareness of contraceptive methods among postpartum women in a tertiary care center J.K. Lon, Govt. medical college Kota. Among the enrolled women in our study $60.04 \%$ were aware about various methods of contraception compared to $55.69 \%$ in Gaikwad RA et $\mathrm{al}^{5}, 69 \%$ in Thapa $S$ et $\mathrm{al}^{6}$ and $70 \%$ in Sharma J et $\mathrm{al}^{7}$.

In present study (table no. 1,2) we observed that majority of postpartum women were of $21-25$ years of age (43.75\%) which were similar to the study of Nair A et $\mathrm{al}^{8}(48 \%)$. The findings of the present study suggest that rural (69.64\%) and uneducated women are still lagging behind in postpartum contraceptive uses. Similar findings were seen in study of Bajracharya A.et $\mathrm{al}^{9}$, Nair $\mathrm{A}$ et $\mathrm{al}^{8}$ and Charusheela Kashyap et $a^{10}$. Our study had more multiparous (54\%) postpartum women than primiparous.

Most of our postpartum women $(40.40 \%)$ had passed $8^{\text {th }}$ standard similar results obtained by other studies Singh A et $\mathrm{al}^{\mathbf{1 1}}$ and Sharma $\mathrm{J}$ et $\mathrm{al}^{\mathbf{7}}$. Most of study population belongs to Hindu community (70.10\%), upper lower and lower socioeconomic classes (64.61\%). In present study most of women were housewives (82.92\%).Our study revealed that knowledge regarding contraception increased with increasing education of women, parity and better socioeconomic standards. Other studies showed comparable results ${ }^{12-15}$. The higher educational status of the women and Upper socioeconomic class were significant predictors of higher level of knowledge about spacing contraception. Association of higher education status with knowledge of spacing contraception has been observed by other Hayat et $\mathrm{al}^{16}$ and Patro BK et $\mathrm{al}^{17}$ in their studies. In our study (table no. 3) among 2690 aware women source of contraceptive information was health care system in $43.86 \%$, mass media (34.57\%), family 
members and other sources were $(21.56 \%)$ respectively. Similar results were found by Nair $A$ et $\left.{ }^{8}\right|^{8}$ and Gaikwad RA et $\mathrm{al}^{5}$, whereas Hayat et $\mathrm{al}^{16}$ and Bajracharya $\mathrm{A}$ et $a \mathrm{l}^{9}$ study media was found to be the most common source of information.

Awareness about barrier methods (Table no. 4), OCPs IUCDs, female sterilization were $80 \%, 58 \%, 76 \%$ and $90 \%$ respectively which is similar to the study by Bajaracharya A et $\mathrm{al}^{9}$. More than one methods was known to $53.90 \%$ of women which was similar to Nair A et al ${ }^{8}(59.17 \%)$ study.

In our study (table no. 5) after post-partum contraception counseling $81.02 \%$ women were willing to use contraception, $18.98 \%$ had no response or neutral attitude. Similar results were obtained in study of Gaikwad RA et $a^{5}$

Table no. 6 shows reasons for non-acceptance (18.98\%) to use contraception after counseling. Majority (48.94\%) wants more children. Both the contraceptive awareness and postpartum acceptance of family planning methods showed a positive correlation with the number of live children. The main reasons for non-acceptance were expectation of a male child similar to few other studies of Delhi, Chandigarh etc. ${ }^{18,19}$

Our study shows (table no. 7) that post counseling $81.02 \%$ women were willing to use contraception, choice preference $36.99 \%$ opted for barrier method, $28.56 \%$ for IUCD, 2.53\% Depo-Provera, 15.98\% for Progesterone pills 1and female sterilization in $15.37 \%$ cases. Similar results were obtained in study by Gaikwad RA et $\mathrm{al}^{5}$ and Makade $\mathrm{KG}$ et $\mathrm{al}^{\mathbf{2 0}}$. Other studies showed an increased inclination towards contraceptive use following postpartum counseling. ${ }^{21}$

\section{CONCLUSION}

Effective contraception benefits both mothers and children by decreasing morbidity and mortality, improving the social and economic status of women and improving the relationship of mother with her children. Our study reveals that education level and socioeconomic status are the major limiting factors in accepting family planning methods. There is a need for proper promotion of spacing methods by policy makers and field workers and motivation of couples to accept them. Counselling during antenatal and postnatal period can go a long way in improving the acceptance. This can be brought about by facilitating the access to more information, education and communication with the immediate postpartum women and improved social and welfare services, education of masses, upliftment of economic standards, strong political commitment, effective health care system. Change in the knowledge, attitude and practice of contraception as a whole constitute important factors in increasing acceptance and usage of spacing and contraception.

Acknowledgement: Authors would like to thank entire team of obstetricians of Govt. Medical College Kota and supporting staff, women who participated in the study for their help and co-operation.

\section{REFERENCES}

1. Population challenges and development goals. Department of Economic and Social Affairs, Population Division, United Nations, New York, 2005.

2. Sunita TH, Desai RM. Knowledge, attitude and practice of contraception among women attending a tertiary care hospital in India. Int J Reprod Contracept Obstet Gynaecol 2013;2(2):172-176.

3. C.D.C. Revised Guidelines for postpartum contraceptive use. www.medscape.org / view article / 746178.

4. Ross JA, Winfrey WL. Contraceptive use, intention to use and unmet need during the extended postpartum period. Int Family Planning Persp 2001;27(1):20-27.

5. Gaikwad RA, Gadappa SN, Deshpande SS. Awareness of contraception in postpartum women in a tertiary care centre. Int J Reprod Contracept Obstet Gynecol 2017;6:3850-4.

6. Thapa S, Rani A, Mishra CP. Knowledge, attitude and belief about contraception in post-partum and post abortal women in a tertiary care centre Int J Reprod Contracept Obstet Gynecol. 2014;3(3):533-9.

7. Sharma J, Dorairajan G, Knowledge and attitude towards contraceptive methods for spacing and decision making factors regarding its use in postpartum women. Int J Reprod Contracept Obstet Gynaecol 2015;4(3):750-754.

8. 8.Nair A, Devi S. Knowledge and attitude of puerperal women towards family planning practices in a tertiary care hospital. J. Evid. Based Med. Healthc. 2017; 4(5), 212-216. DOI: 10.18410/jebmh/2017/41

9. Bajracharya A. Knowledge, Attitude and Practice of Contraception among Postpartum Women Attending Kathmandu Medical College Teaching Hospital. Kathmandu Univ Med J 2015;52(4):292-7.

10. Charusheela Kashyap, Ipseeta Ray Mohanty, Pratima Thamke, Y. A. Deshmukh,Acceptance of Contraceptive Methods Among Postpartum Women in a Tertiary Care Center,The Journal of Obstetrics and Gynecology of India (March-April 2017);67(2):91-97.

11. Singh A, Meena P, Radhakrishnan G, A knowledge, attitude and practice study on awareness and acceptance of contraception in postpartum women in a tertiary care hospital. Int J Reprod Contracept Obstet Gynecol 2016;5:1921-1924.

12. 12.Murarkar SK, Soundale SG. Epidemiological correlates of contraceptive prevalence in married 
women of reproductive age group in rural area. National J Comm Med 2011;2(1):78-81.

13. 13.Chankapa YD, Tscring D, Kar S, Sociodemographic variables of contraceptive practice in Sikkim. J Pharm Bioall Sci 2011;3(3):368-374.

14. 14.Kanojia JK, Nirbhavane NC, Toddywala S, Dynamics of contraceptive practice amongst urban Indian women. Natl Med J India 1996;9(3):109-112.

15. 15.Romero-Gutierrez G, Garcia-Vazquez MG, HuertaVargas LF, Postpartum contraception in LeOn, Mexico: a multivariate analysis. Eur J Contracept Reprod Health Care 2003;8(4):210-216.

16. Hayat H, Khan PS, Imtiyaz B, Hayat G, Hayat R. Knowledge, attitude and practice of contraception in rural Kashmir. J Obstet Gynecol India 2013;63(6):4104.
17. Patro BK, Kant S, Baridalyne N, Goswami AK. Contraceptive practice among married women in a resettlement colony of Delhi. Health Popul Perspect Issues. 2005;28(1):9-16.

18. Sharma AK, Graver V, Agarwal OP, Dubey KK. Pattern of contraceptive use by residents of a village in South Delhi. Indian J Public Health. 1997;41(3):75-8.

19. Singh K, Swami HM, Dhawan S, Bhatia SPS. A study of family planning practices in rural areas of Chandigarh. Indian J Prev Soc Medt. 1999;30(324):107-10.

20. Makade KG, Padhyegurjar M, Padhyegurjar SB, Kulkarni RN. Study of contraceptive use among married women in a slum in Mumbai. National J Comm Med. 2012;3(1):40-3.

21. Mecina R, Lundgran R, Final report. Tegucigalpa, Honduras. Ministry of Health and INOPAL III/ Population Council August 1998.

Source of Support: The author(s) received no financial support for the research, authorship, and/or publication of this article.

Conflict of Interest: The author(s) declared no potential conflicts of interest with respect to the research, authorship, and/or publication of this article.

For any question relates to this article, please reach us at: editor@globalresearchonline.net New manuscripts for publication can be submitted at: submit@globalresearchonline.net and submit_ijpsrr@rediffmail.com

\begin{tabular}{|l|l|}
\hline & $\begin{array}{l}\text { Corresponding author biography: Dr. Girdhar Gopal Nagar } \\
\text { Dr. Girdhar Gopal Nagar S/O Sh. Radhaballabh Nagar } \\
\text { Senior Resident in department of Gynaecology and Obstetrics Government Medical } \\
\text { College Kota, Rajasthan (India). } \\
\text { M.S. in Obst. And Gynae. from Dr. S.N. Medical College Jodhpur, Rajasthan (India). } \\
\text { M.B.B.S. from Government Medical College Kota, Rajasthan (India). } \\
\text { V/P Kishanganj Dist. Baran Rajasthan Pin 325216. }\end{array}$ \\
\hline
\end{tabular}

